\title{
Functional Feeding Group composition and attributes: evaluation of freshwater ecosystems in Atlantic Forest, Brazil
}

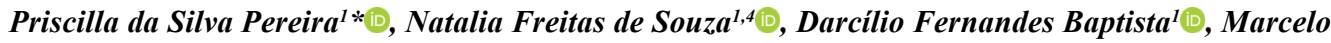 \\ Ribeiro-Alves ${ }^{\circledR}$, Helena Lucia Carneiro Santos ${ }^{2}$ \& Daniel Forsin Buss ${ }^{1}$ \\ ${ }^{I}$ Fundação Oswaldo Cruz, Instituto Oswaldo Cruz, Laboratório de Avaliação e Promoção da Saúde Ambiental, \\ Rio de Janeiro, RJ, Brasil \\ ${ }^{2}$ Fundação Oswaldo Cruz, Instituto Oswaldo Cruz, Laboratório de Estudos Integrados em Protozoologia, Rio \\ de Janeiro, RJ, Brasil \\ ${ }^{3}$ Fundação Oswaldo Cruz, Instituto Nacional de Infectologia Evandro Chagas, Laboratório de Pesquisa Clínica \\ em DST / AIDS, Rio de Janeiro, RJ, Brasil \\ ${ }^{4}$ Universidade Federal do Rio de Janeiro, Departamento de Ecologia, Rio de Janeiro, RJ, Brasil \\ *Corresponding author: Priscilla da Silva Pereira, e-mail: prispereira.bio@gmail.com
}

PEREIRA, P.S., SOUZA, N.F., BAPTISTA, D.F., RIBEIRO-ALVES, M., SANTOS, H.C., BUSS, D.F. PEREIRA, P.S., SOUZA, N.F., BAPTISTA, D.F., RIBEIRO-ALVES, M., SANTOS, H.C., BUSS, D.F. Functional Feeding Group composition and attributes: evaluation of freshwater ecosystems in Atlantic Forest, Brazil. Biota Neotropica 21(2): e20201016. https://doi.org/10.1590/1676-0611-BN-2020-1016

\begin{abstract}
Benthic macroinvertebrates Functional Feeding Group (FFG) have been used to determine aquatic assemblage dynamics and as a biomonitoring tool. The main goals of this study were to assess the effects of stream variables on the abundance and richness of FFGs and evaluate ecosystem attributes (FFG ratios) as a tool to assess ecological conditions of Atlantic Rainforest streams. We sampled 146 sites with different impairment conditions in Rio de Janeiro, Brazil. Richness was significantly different among impairment conditions for all FFGs. Mixed-effect models show that aquatic macroinvertebrate FFGs differed in their responses to abiotic variables for abundance and richness. Also, they were reduced in the impaired sites when compared to intermediate and reference sites. The FFG ratio indicated significant differences along the impairment gradient. The FFG ratio analysis was shown to be a fast and cheap tool that can be used for monitoring aquatic ecosystems in the Atlantic Forest biome. However, further studies are required to calibrate the method specifically for the Atlantic Forest region.
\end{abstract}

Keywords: Macroinvertebrate; streams; ecosystem attributes; impairment.

\section{Composição e atributos de Grupos Funcionais Alimentares: avaliação de ecossistemas de água doce na Mata Atlântica, Brasil}

Resumo: Os Grupos Funcionais de Alimentação (GFA) são utilizados para determinar a dinâmica da comunidade de macroinvertebrados bentônicos e como uma ferramenta de biomonitoramento. Os principais objetivos deste estudo foram: avaliar os efeitos de variáveis de riacho na abundância e riqueza de GFAs e os atributos do ecossistema (razão GFA) como uma ferramenta para avaliar as condições ecológicas dos córregos da Mata Atlântica. Foram amostrados 146 locais com diferentes condições de impacto no Rio de Janeiro, Brasil. A riqueza foi significativamente diferente com as condições de impacto entre todos os GFA. Os modelos de efeito misto mostraram que os GFA diferiam em suas respostas às variáveis abióticas quanto à abundância e riqueza. Além disso, eles diferem nas áreas impactadas quando comparados as áreas intermediária e de referência. A razão de GFA encontrou diferenças significativas ao longo do gradiente de impacto. A análise da razão de GFA evidenciouse uma ferramenta rápida e barata, com potencial para ser utilizada no monitoramento de ecossistemas aquáticos no bioma Mata Atlântica. No entanto, mais estudos serão necessários para calibrar o método especificamente para a região da Mata Atlântica.

Palavras-chave: Macroinvertebrados; rios; atributos do ecossistema; impacto. 


\section{Introduction}

Streams and rivers exhibit a high biological diversity and provide critical ecological functions and services. However, they are among the most threatened ecosystems due to anthropogenic activities, such as human settlements, industries pollution, and agriculture, which have led to increased habitat loss, higher pollution levels, invasions of exotic species, and the changing climate (Allan \& Castilho 2007, Ceneviva-Bastos et al. 2017). Climate change tends to exacerbate anthropogenic stress due to increased water temperature, salinity, and changes in hydrological cycles, which results in shifting rainfall patterns and flow fluctuations (Durance 2007).

Biomonitoring has long been recognized as a tool to screen environmental health changes taking place in the environment (Barbour et al. 1999). Benthic macroinvertebrate is among the most used organisms to assess the ecological condition. Macroinvertebrates are a primary food source for fishes and other organisms (Rosenberg $\&$ Resh 1993). They are abundant in most streams, even small ones, have species at different trophic levels, with a wide range of pollution tolerance, and sampling is relatively easy at a low cost (Barbour et al. 1999, Bonada et al. 2006, Henriques-Oliveira \& Nessimian 2010, Gieswein et al. 2019).

Two main approaches have been used in biomonitoring programs to assess freshwater macroinvertebrates: one uses richness and diversity indices. and the other uses functional attributes (Cummins 1973, Cummins \& Klug 1979, Merritt et al. 1999, Merritt et al. 2002, Cummins 2018). The functional attributes based on morphology and feeding behavior. According to Dedieu et al. (2015), biological traits of freshwater organisms, such as feeding behavior, are useful tools for detecting change along gradients of anthropogenic disturbance. In freshwater ecology, macroinvertebrates Functional Feeding Groups (FFGs) have been used to conceptualizing community dynamics and assessing ecological status (Vannote et al. 1980). The attributes related to the structure and function give indicators of aquatic ecosystem conditions (Hawkins \& Sedell 1981, Ceneviva-Bastos et al. 2017, Fugère et al. 2018). According to Vannote et al. (1980), trophic interactions can affect ecological processes by directly influencing flows of the distribution of energy and resources within the assemblage. Thus, functional analysis focuses on the type of food and food acquisition. FFGs are defined by the way organisms feed: (1) gathering collectors - feed on small organic matter particles deposited in the river bed; (2) filtering collectors - capture, by filtration, small organic matter particles suspended in the water column; (3) scrapers - scrape hard surfaces and feed on algae, bacteria, fungi, and dead organic matter adsorbed on substrates, (4) predators - swallow whole prey or body tissue fluids and (5) shredders - chew leaves or tissue from living vascular plant or dead wood and debris (Cummins 1973).

According to Merritt et al. (1996), the use of FFG ratio can estimate attributes related to the stream ecosystem. The FFG ratio serves as a surrogate for stream ecosystem attributes. These attributes include a trophic state (Autotrophy/Heterotrophy), the linkage between to functioning the riparian vegetation and the shredder, relative amounts of coarse and organic particles (transported and stored in the environment), the stability of the habitat, and ascendant control for predators to be driven by prey availability. The FFG ratio is a rapid and integrating technique used to establish a protocol for characterizing the ecological condition.
This approach has been used to assess river conditions in Brazil. Cummins et al. (2005) used an FFG ratio to evaluate the sites ecological conditions in Southern Brazil, and Couceiro et al. (2011) assessed streams located in Brazil's Amazon forest. Multimetric and predictive indices for larger-scale protocols also used FFG components in South America (Baptista et al. 2007, Buss et al. 2015, Macedo et al. 2016, Oliveira et al. 2019, Souza et al. 2019).

This study's main goals were to evaluate all FFG categories and the effects of abiotic variables on abundance, richness, and FFG ratio to assess the ecological conditions of Atlantic Forest streams. In this context, this study used FFG and their ratios to assess the ecological conditions of Atlantic Forest streams.

\section{Material and Methods}

\section{Study area}

The Atlantic Forest region in Rio de Janeiro State is classified as the tropical state with a rainy summer season, with the most mountainous areas and plateaus classified as humid subtropical, with a hot summer and without a dry season or a dry winter (Alvares et al. 2013). Temperatures oscillate between $15^{\circ} \mathrm{C}$ and $28^{\circ} \mathrm{C}$, and annual rainfall is around $1,000-1,500 \mathrm{~mm}$.

The Rio de Janeiro state is composed of a group of coastal plains separated by hills and two mountain chains that run parallel to the ocean (Serra do Mar, ranging from altitudes 0-2000 ma s.l and Serra da Mantiqueira, ranging from 800 to 2500 m.a.s.l). The coastal plains are located at the piedmont of Serra do Mar mountain range, with altitudes about 200 ma.s.1.. It is a depositional zone formed by marine, lacustrine, and fluvial sedimentation processes (Brasil 1983). This region is affected by high impact by urban areas or agriculture and livestock grazing, making minimally impacted areas (reference) scarce. The mountain chains are located at higher altitudes (from $>200$ ma.s.l. to around 1,800 ma.s.l) with high slope and steep scarps. Most sites were sampled within or near protected areas (conservation units), which had a low to moderate impact on agricultural activities. For this reason, this region presents the most extensive riparian vegetation and forest fragments.

The Neotropical Atlantic Forest is one of the biodiversity hotspots worldwide. However, the biome has lost $88 \%$ of its original extent, and remnants are mostly spread throughout the higher parts of mountains, interspersed with agriculture and pasture (Ribeiro et al. 2011).

We selected sites based on the ad hoc indication and previous knowledge of the area to represent sites classified, a posteriori, as a reference, intermediate, or impaired. Sites classified as "reference" should meet all the following criteria: "optimal" or "good" environmental conditions according to the Habitat Assessment Protocol (HAP) (Barbour et al. 1999 - see rationale below); dissolved oxygen concentration $\geq 6 \mathrm{mg} / \mathrm{l}, \mathrm{pH}$ between 6 and 8 , absence of channelization, and $<40 \%$ of the upstream area affected by urban areas. For a site to be classified as "impaired," the following criteria should be met: "poor" classification according to the HAP; dissolved oxygen $<6$ $\mathrm{mg} / \mathrm{l}$. Intermediate sites had characteristics between these two classes. We sampled 146 sites of the Atlantic Forest region in Rio de Janeiro State (74 references, 38 intermediates, and 34 impaireds) during the dry season. Sampled sites ranged from 1st to 5th order according to Strahler classification (Figure 1). 


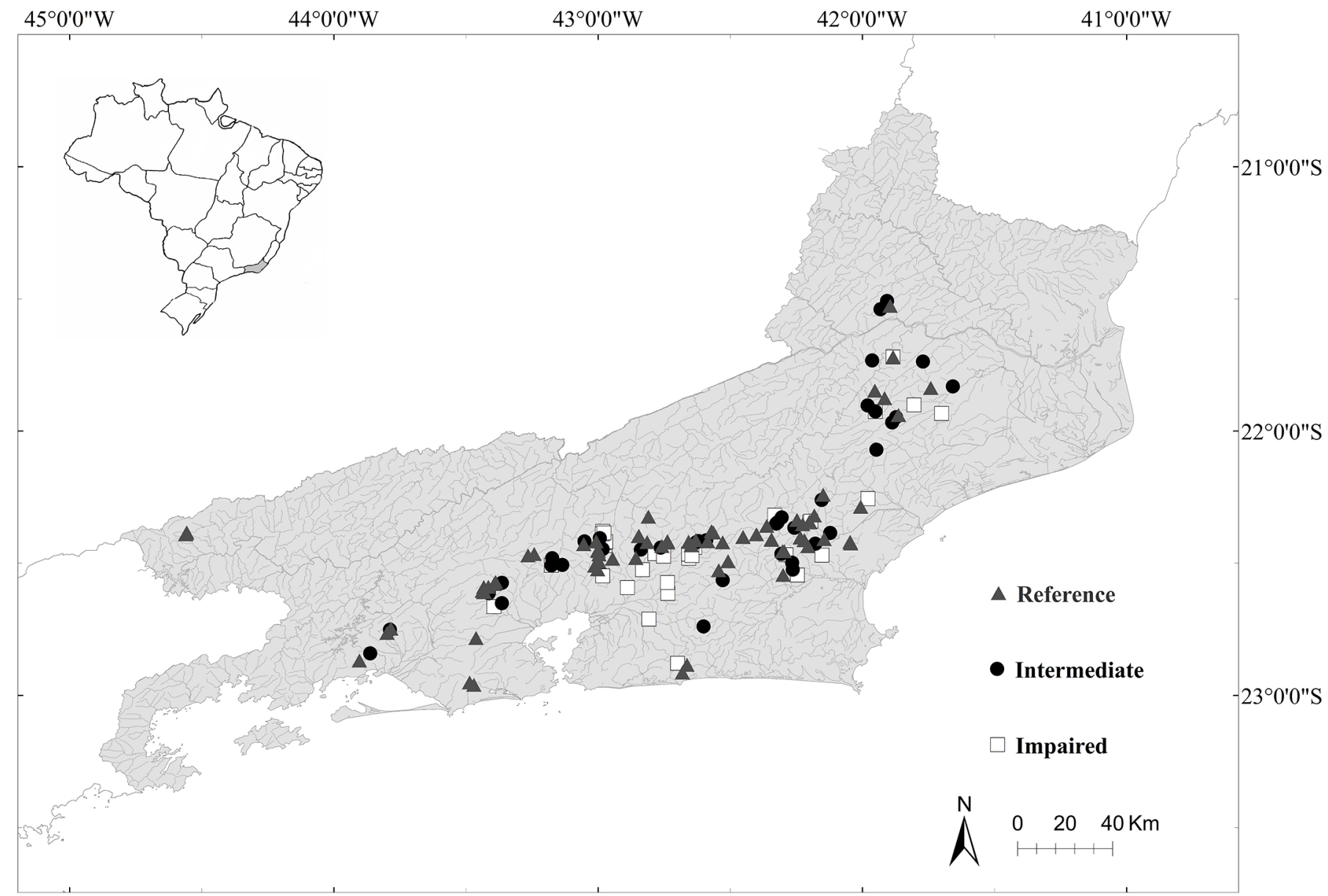

Figure 1. Map of the study area, showing the sampling sites in the Rio de Janeiro State, Brazil, indicating gradient of impairment (reference, intermediate and impaired).

\section{Sample site evaluation}

In each sampling site, the following physicochemical variables were recorded in the field: dissolved oxygen (DO; YSI 550A equipment), pH (LabConte MPA 210p), and Conductivity (Cond; using a LabConte MCA 150p). Water samples were preserved in sterile plastic bags (whirl-pak), according to APHA (2000). In the laboratory, the concentration of Ammonia $\left(\mathrm{NH}_{3}\right)$ was determined using a HACH (DR 2500). Chloride (Ch), total alkalinity (TA), total hardness $(\mathrm{TH})$, and calcium $(\mathrm{Ca})$ were determined by the titrimetric method following APHA (2000). Sampling sites were also classified in the field by the HAP (Barbour et al. 1999). The HAP has ten environmental parameters, such as substrate availability for colonization by benthic fauna, water velocity, embeddedness (pool variability for low-gradient streams), channel condition (sinuosity for low-gradient streams), sediment deposition, margin stability, and riparian vegetation. For each variable, a score between 0 and 20 was assigned. Sites were classified conforming to the mean score obtained, as follows: 0-5 "Poor," 5.1-9.9 "Regular," 10-14.9 "Good," and 15-20 "Excellent" environmental condition (Barbour et al. 1999).

\section{Biological samples}

Macroinvertebrates were sampled by using a kick-net with a mesh size of $500 \mu \mathrm{m}$. For this, 20 samples $\left(20 \mathrm{~m}^{2}\right)$ were taken proportionally to the substrates available at each site, according to the multi-habitat method (Barbour et al. 1999). Samples were conserved in the field in $80 \%$ ethanol and taken to the laboratory. In the lab, samples were washed to remove coarse organic matter, such as leaves and twigs. The remaining material was deposited into a sampler $(64 \times 36 \mathrm{~cm})$, divided into 24 quadrants, each measuring $10.5 \times 8.5 \mathrm{~cm}$ (Fiocruz, Patent application number PCT/BR2011/000144). This method is used to assure the randomness of biological assessments, as it is less subject to the variability of team members (Oliveira et al. 2011).

\section{Functional Feeding Group classification and ratios}

Fauna and FFGs were attributed to each taxon based on keys from regional entomofauna studies (Nessimian 1997, Baptista et al. 2006, Henriques-Oliveira \& Nessimian 2010, Fernandes 2015) in Neotropical studies (Velásques \& Miserendino 2003, Tomanova et al. 2006, Brasil et al. 2014) and the USA reference (Merritt \& Cummins 1996). Also, five FFG ratios, adapted from Merritt et al. (1996), were used (Table $1)$. 
Pereira, PS. et al.

Table 1. Functional Feeding Group (FFG) ratios modified from Merritt \& Cummins (1996).

\begin{tabular}{|c|c|c|c|}
\hline Ecosystem attributes & Symbols & FFG ratios & Criteria levels \\
\hline Autotrophy/Heterotrophy index & $\mathrm{A} / \mathrm{H}$ & Scraper/shredder + total collector & Autotrophic $>0.75$ \\
\hline Shredder index & CPMO/FPOM & Shredder/total collector & Shredder availability $>0.25$ \\
\hline Habitat Stability index & HSI & $\begin{array}{l}\text { Scraper + filtering collector/ } \\
\text { shredder + gathering collector }\end{array}$ & Stable substrates $>0.50$ \\
\hline
\end{tabular}

The autotrophy and heterotrophy index $(\mathrm{A} / \mathrm{H})$ relates primary productivity to total community respiration. The $\mathrm{A} / \mathrm{H}$ serves as indicated that the stream is autotrophy (autochthonous organic matter derived algae or rooted vascular aquatic plants) or heterotrophy (allochthonous organic matter resultant from the riparian zone). The ratio between coarse particulate organic matter and fine particulate organic matter (CPOM/FPOM) provides insights into the quality of the riparian zone cover and the availability of litter used by shredders. The ratio of fine particulate organic matter and benthic fine particulate organic matter (TFPOM/BFPOM) measure the availability of relative amounts of coarse and organic particles (transported and stored in the environment). The habitat stability index (HSI) indicates the abundance of bottom substrates for the colonization of macroinvertebrates such as stones, wood, and aquatic plants. The predator-prey index (Predator) reflects top-down control by predators.

\section{Data analysis}

Abundance and richness of the FFG in each sampled site were calculated to characterize the differences in community trophic structure along the gradient of impairment. Taxa that could be assigned to more than one FFG were equally divided among the possible groups (Mendes et al. 2017). Differences among these groups were estimated by contrasts of the expected mean marginal values obtained from multivariate mixed linear models fitted using the maximum likelihood estimator.

The fixed/systematic component of models included the impairment gradient, while the random component included the river basin of each sampled stream. Also, to eliminate the dependence among the closest sampled stream, a Gaussian spatial correlation structure was considered. For the adjusted models, a graphical analysis of residuals was performed to confirm their randomness. In analyses of model marginal mean estimates contrasts, adjustments of the confidence level were made by Sidak's method, and p-value adjustments were made by multiple comparisons using Tukey's method. Stepwise searches based on the minimization of the Akaike Information Criterion (AIC), in both forward and backward directions, were used to select the optimal, nonredundant, mixed-effect model (similar to the one described above) of abiotic variables (i.e., Stream Width, Altitude, $\mathrm{DO}, \mathrm{pH}, \mathrm{Cond}, \mathrm{NH}_{3}, \mathrm{Ch}$, TH, TA, Ca and, HAP) on the abundance and richness of each FFG. The level of significance, alpha $=0.05$, was used in the analyses. Analyses were performed in R software version 3.6.1 (R Development Core Team, 2018, http://www.r-project.org/) with functionalities augmented by the packages 'emmeans' (Russell \& Lenth 2020), used in the obtainment of estimated marginal means of the fitted mixed models, and 'nlme' (Pinheiro et al. 2020), used in the fitting of those models.

\section{Results}

A total of 108,282 aquatic benthic macroinvertebrates distributed in 176 taxa were collected during the study. In general, contrasts after the multivariate mixed linear model estimated marginal means showed significant differences along with the impairment gradient sites (a, reference - intermediate; b, reference - impaired; and, c, intermediate - impaired).

Filtering collector was the most abundant FFG regardless of impairment classes, and Simuliidae was the dominant taxa along the impairment gradient (reference, intermediate, and impaired sites). Figure 2 shows that estimated marginal mean abundance differed along the impairment gradient for scrapers $(b=99.97, \mathrm{p}<0.000001$; and, $\mathrm{c}=$ 87.35, $\mathrm{p}=0.006)$ and shredders $(\mathrm{a}=29.83, \mathrm{p}=0.0005$; and, $\mathrm{b}=46.86$, $\mathrm{p}<0.000001)$. Gathering and filtering collectors, and predators had their highest mean values at intermediate sites, while scrapers and shredders had higher mean values at reference sites.
A

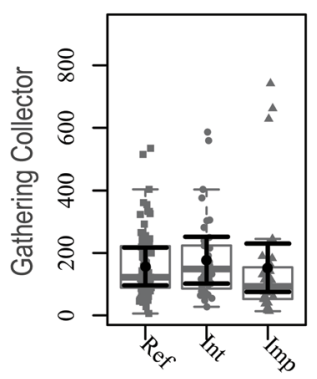

B

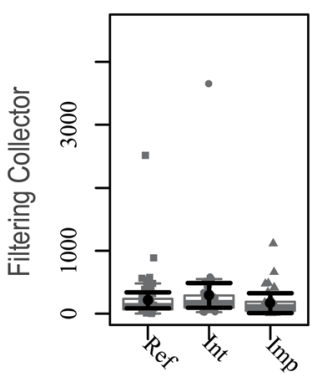

C

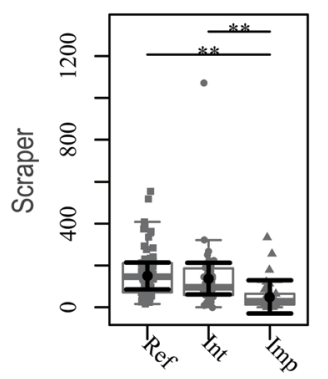

$\mathrm{D}$

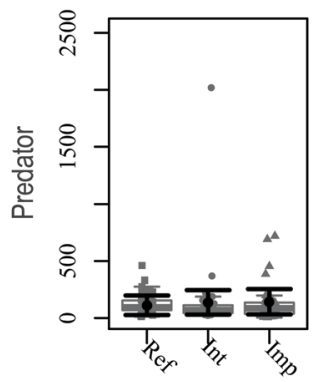

$\mathrm{E}$

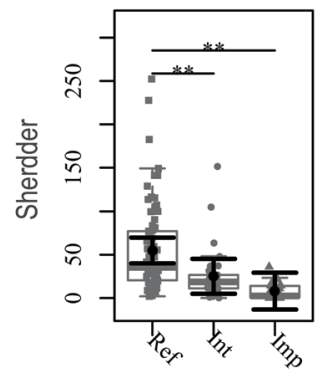

Figure 2. Distributions of samples and estimatives for FFG abundance along the impairment gradient (Ref - Reference, Int - Intermediate, and Imp - Impaired). Box-and-whisker and strip plots (gray) representing samples distribution of FFG abundance. Dots and lines (black) representing estimated means and $95 \%$ confidence intervals obtained after multivariate mixed linear models fitted using the maximum likelihood estimator. 
A significant decrease for marginal mean estimates of all FFG richness was observed along the impairment gradient (Figure 3). All FFGs showed differences along the impairment gradient: gathering collector $(\mathrm{a}=2.97, \mathrm{p}=0.001 ; \mathrm{b}=8.72, \mathrm{p}<0.000001$; and, $\mathrm{c}=5.76$, $\mathrm{p}<0.000001)$; filtering collector $(\mathrm{b}=1.60, \mathrm{p}<0.000001$; and, $\mathrm{c}=1.15$, $\mathrm{p}=0.0001)$; scraper $(\mathrm{a}=2.62, \mathrm{p}=0.002 ; \mathrm{b}=7.10, \mathrm{p}<0.000001$; and, $\mathrm{c}=$ $4.49, \mathrm{p}<0.000001)$; predator $(\mathrm{a}=1.93, \mathrm{p}=0.01 ; \mathrm{b}=6.15, \mathrm{p}<0.000001$; and, $\mathrm{c}=4.22, \mathrm{p}<0.000001)$; and shredders $(\mathrm{a}=1.57, \mathrm{p}<0.000001 ; \mathrm{b}=$ $3.49, \mathrm{p}<0.00001 ;$ and, $\mathrm{c}=1.91, \mathrm{p}<0.000001)$. Similarly, mean richness numbers of all FFGs decreased along the impairment gradient.

As expected, abiotic variables, i.e., DO, $\mathrm{pH}$, Cond, TH, TA, Ca, and HAP, were significantly different along the impairment gradient (Supplementary Material: Appendix 1). Stepwise searches showed the most relevant among these abiotic variables on the abundance and richness variance of aquatic macroinvertebrate FFG (Table 2). Overall, the coefficients of determination $\left(\mathrm{R}^{2}\right)$ of the optimal models selected were low for the abundance of macroinvertebrate FFG, ranging from 0.14 to 0.34 ( $p<0.001$ for all), suggesting lower importance than anticipated of these abiotic variables on the FFG abundance variation among sites.

Estimated marginal means based on regression analyses (mixedeffect models) showed that the altitude was a significant abiotic variable for all FFG abundance (except for the filtering collector). Nonetheless, for the filtering collector and the predator, we observed a positive linear correlation between abundance along the impairment gradient (e.g., $\mathrm{NH}_{3}$ and Calcium).
Different results were found for abiotic variables and richness of FFGs (Table 3). Optimal models selected for the richness of FFG the $\mathrm{R}^{2}$ were moderate, ranging from 0.36 to 0.52 ( $p<0.001$ for all), suggesting higher importance of abiotic variables on the variation of FFG richness than for abundance variance. Reductions were correlated to the increase of $\mathrm{NH}_{3}$ for all FFG. Calcium $(\mathrm{Ca})$ also was negatively correlated with richness among predators and shredders. The better tendencies were also observed for Total Hardness (TH) for gathering collectors, filtering collectors, and scrapers, and for Chloride $(\mathrm{Ch})$ for gathering collectors, filtering collectors, scrapers, and predators. As expected, these reductions in the richness of FFG were significantly between the intermediate and impaired sites and the reference sites (Figure 3).

In general, estimated marginal means for FFG ratios showed significant differences among the impairment gradient sites. Significant differences along the impairment gradient were found for the Autotrophic/Heterotrophic index $(\mathrm{A} / \mathrm{H})$ (Figure $4 \mathrm{~A}$; $\mathrm{a}=$ $0.16, p=0.02 ; b=0.26, p<0.001)$. Regardless of the position along the impairment gradient, most sites were below the $\mathrm{A} / \mathrm{H}$ level of 0.75 being Heterotrophic $(91.1 \%)$, indicating the dependence of the stream food web on the availability of allochthonous riparian organic matter. For $\mathrm{A} / \mathrm{H}$ numbers for reference, intermediate and impaired were $0.49,0.33$, and 0.23 , respectively. Coarse Particulate Organic Matter/Fine Particulate Organic Matter index (CPOM/ FPOM) is an indicator of the availability of food resources for shredders. For this index (Figure 4B) we found a significant difference along the impairment gradient $(b=0.17, p=0.006)$.
A

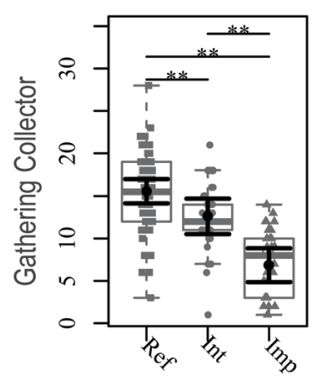

B

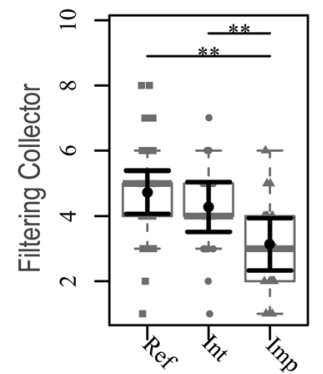

$\mathrm{C}$

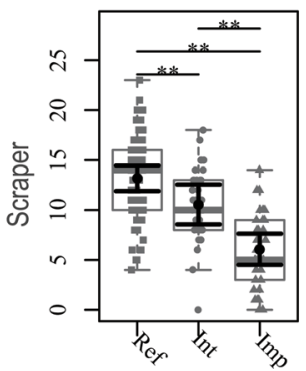

$\mathrm{D}$

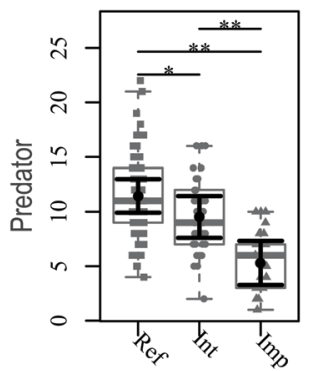

$\mathrm{E}$

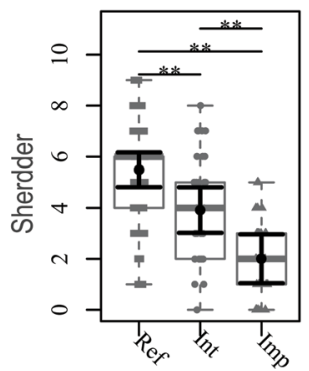

Figure 3. Distributions of samples and estimatives for FFG richness along the impairment gradient (Ref - Reference, Int - Intermediate, and Imp - Impaired). Boxand-whisker and strip plots (gray) representing samples distribution of FFG richness. Dots and lines (black) representing estimated means and $95 \%$ confidence intervals obtained after multivariate mixed linear models fitted using the maximum likelihood estimator.

A

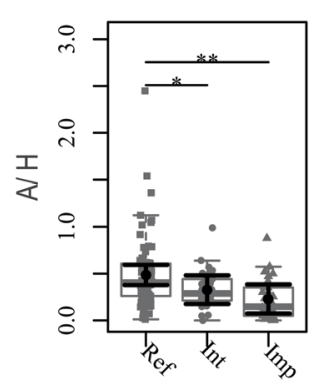

B

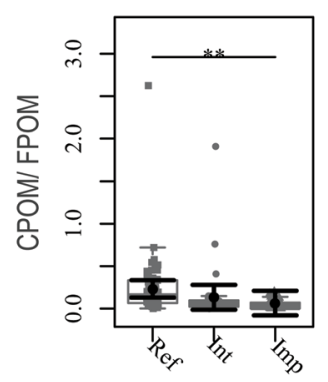

$\mathrm{C}$

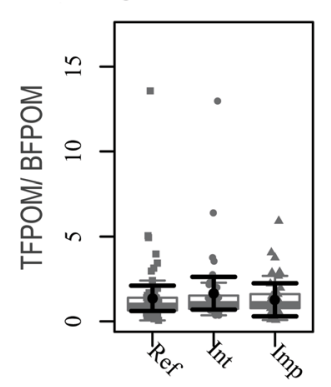

$\mathrm{D}$

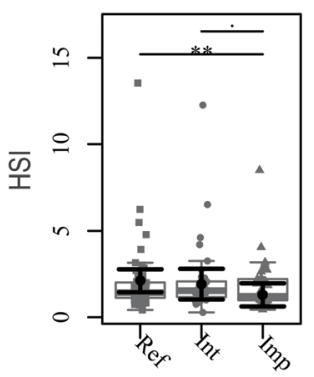

E

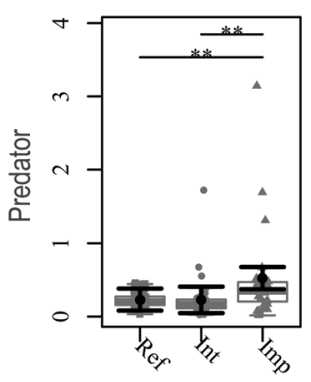

Figure 4. Distributions of samples and estimatives for FFG ratios along the impairment gradient (Ref - Reference, Int - Intermediate, and Imp - Impaired). Boxand-whisker and strip plots (gray) representing samples distribution of A/H (Autotrophy and Heterotrophy index), CPOM/FPOM (Coarse Particulate Organic Matter and Fine Particulate Organic Matter index), TFPOM/BFPOM (Transport of Fine Particles Organic Matter, and Benthic Fine Particles Organic Matter index), HSI (Habitat Stability index), and Predator (Predator-prey index) along the impairment gradient. Dots and lines (black) representing estimated means and $95 \%$ confidence intervals obtained after multivariate mixed linear models fitted using the maximum likelihood estimator. 
Pereira, PS. et al.

Reference sites had a mean CPOM/FPOM ration of 0.23 , close to the ratio level cut $(>0.25)$. Intermediate sites showed lower shredder interaction with the riparian vegetation (mean $=0.13$ ), and, as expected, impaired sites had shredders very underrepresented (mean $=0.06)$. For the Transport of Fine Particles Organic Matter/Benthic Fine Particles Organic Matter index (TFPOM/BFPOM) no differences were found along the impairment gradient (Figure 4C). TFPOM/BFPOM indexes were of good quality independently of the impairment gradient (according to the criteria ratio level $>0.50$ ), with estimated mean marginal values of 1.36, 1.66, and 1.27, for reference, intermediate, and impaired sites respectively. For the Habitat Stability index (HSI) (Figure 4D), a significant difference along the impairment gradient was found $(b=0.82$, $\mathrm{p}<0.001$ ), with estimated mean values of 2.11 and 1.92 for reference, and intermediate sites, respectively, which indicates an abundance of stable substrates. The estimated marginal mean value was 1.29 for impaired sites above the ratio level cut $(>0.50)$ for a stable substrate.

Table 2. Stepwise searches based on the Akaike information criterion (AIC) minimization, in both forward and backward directions, of abiotic variables on the abundance of macroinvertebrate Functional Feeding Groups (FFG).

\begin{tabular}{|c|c|c|c|c|c|c|}
\hline FFG & Variables & $\beta$ & Std.Error & DF & t.value & p.value \\
\hline Gathering-collector & (Intercept) & 372.957 & 90.637 & 134 & 4.115 & $<0.001$ \\
\hline $\mathrm{AIC}=1828.64$ & Width (m) & 2.225 & 1.145 & 134 & 1.944 & 0.054 \\
\hline \multirow{2}{*}{$\begin{array}{l}\text { L. Ratio= 22.99; } \\
p<0.001\end{array}$} & $\mathrm{pH}$ & -31.791 & 12.112 & 134 & -2.625 & 0.010 \\
\hline & Log10_Ch (mg/L) & -190.588 & 76.806 & 134 & -2.481 & 0.014 \\
\hline $\mathrm{AIC}=2109.13$ & Width (m) & 8.631 & 2.217 & 131 & 3.894 & $<0.001$ \\
\hline $\mathrm{R}^{2}=0.24$ & $\log 10 \_\mathrm{NH}_{3}(\mathrm{mg} / \mathrm{L})$ & 1945.715 & 370.471 & 131 & 5.252 & $<0.001$ \\
\hline \multirow{3}{*}{$\begin{array}{l}\text { L. Ratio= 63.75; } \\
p<0.001\end{array}$} & $\mathrm{DO}(\mathrm{mg} / \mathrm{L})$ & 44.067 & 13.699 & 131 & 3.217 & 0.002 \\
\hline & Log10_Ca (mg/L) & 1276.571 & 269.336 & 131 & 4.740 & $<0.001$ \\
\hline & Log10_TA & -287.848 & 198.065 & 131 & -1.453 & 0.149 \\
\hline $\mathrm{AIC}=1801.01$ & Width (m) & 1.671 & 0.698 & 131 & 2.394 & 0.018 \\
\hline $\mathrm{R}^{2}=0.14$ & Altitude (m) & 0.092 & 0.033 & 131 & 2.766 & 0.006 \\
\hline L. Ratio= 52.07; & DO (mg/L) & -13.712 & 4.358 & 131 & -3.146 & 0.002 \\
\hline \multirow[t]{4}{*}{$\mathrm{p}<0.001$} & $\mathrm{pH}$ & -24.231 & 9.417 & 131 & -2.573 & 0.011 \\
\hline & Log10_Ch & -117.153 & 51.677 & 131 & -2.267 & 0.025 \\
\hline & HAP & 3.897 & 1.091 & 131 & 3.571 & $<0.001$ \\
\hline & Log10_Cond $(\mathrm{S} / \mathrm{cm})$ & 91.922 & 51.444 & 131 & 1.787 & 0.076 \\
\hline Predator & (Intercept) & 328.199 & 122.679 & 133 & 2.675 & 0.008 \\
\hline $\mathrm{AIC}=1466.86$ & Altitude (m) & 0.030 & 0.009 & 132 & 3.504 & 0.001 \\
\hline $\mathrm{R}^{2}=0.34$ & Log10_NH 3 (mg/L) & -132.232 & 67.989 & 132 & -1.945 & 0.054 \\
\hline L. Ratio= 69.46; & $\mathrm{DO}(\mathrm{mg} / \mathrm{L})$ & 3.375 & 1.461 & 132 & 2.311 & 0.022 \\
\hline \multirow[t]{3}{*}{$\mathrm{p}<0.001$} & Log10_Ca (mg/L) & -46.292 & 29.530 & 132 & -1.568 & 0.119 \\
\hline & $\log 10 \_\mathrm{TA}(\mathrm{mg} / \mathrm{L})$ & 60.436 & 17.327 & 132 & 3.488 & 0.001 \\
\hline & HAP & 2.898 & 0.609 & 132 & 4.758 & $<0.001$ \\
\hline
\end{tabular}

AIC- Akaike Information Criterion, $\mathrm{R}^{2}$ - Coefficient of Determination, L.Ratio- Likelihood Ratio, $\mathrm{p}$-value- $\mathrm{p}$-value after Likelihood Ratio Test, DF - Degrees of Freedom. Log10_NH $\mathrm{NH}_{3}$-Ammonia; Log10_TH- Total Hardness, Log10_Ch-Chloride, HAP- Habitat Assessment Protocol DO- Dissolved Oxygen and Log10_TATotal Alkalinity and Log10_Ca-Calcium. 
Finally, for the predator-prey index (Predator) (Figure 4E) significant differences were found along the impairment gradient $(b=-0.29$, $\mathrm{p}<0.000001 ; \mathrm{c}=-0.30, \mathrm{p}<0.000001)$. Impaired sites showed the highest estimated marginal mean value, 0.52 , compared to the reference $(0.23)$ and intermediate sites (0.23). Most ratios were within the range of criteria levels for reference and intermediate sites and an overabundance of predators at impaired sites.

Table 3. Stepwise searches based on the Akaike information criterion (AIC) minimization, in both forward and backward directions, of abiotic variables on the richness of macroinvertebrate Functional Feeding Groups (FFG).

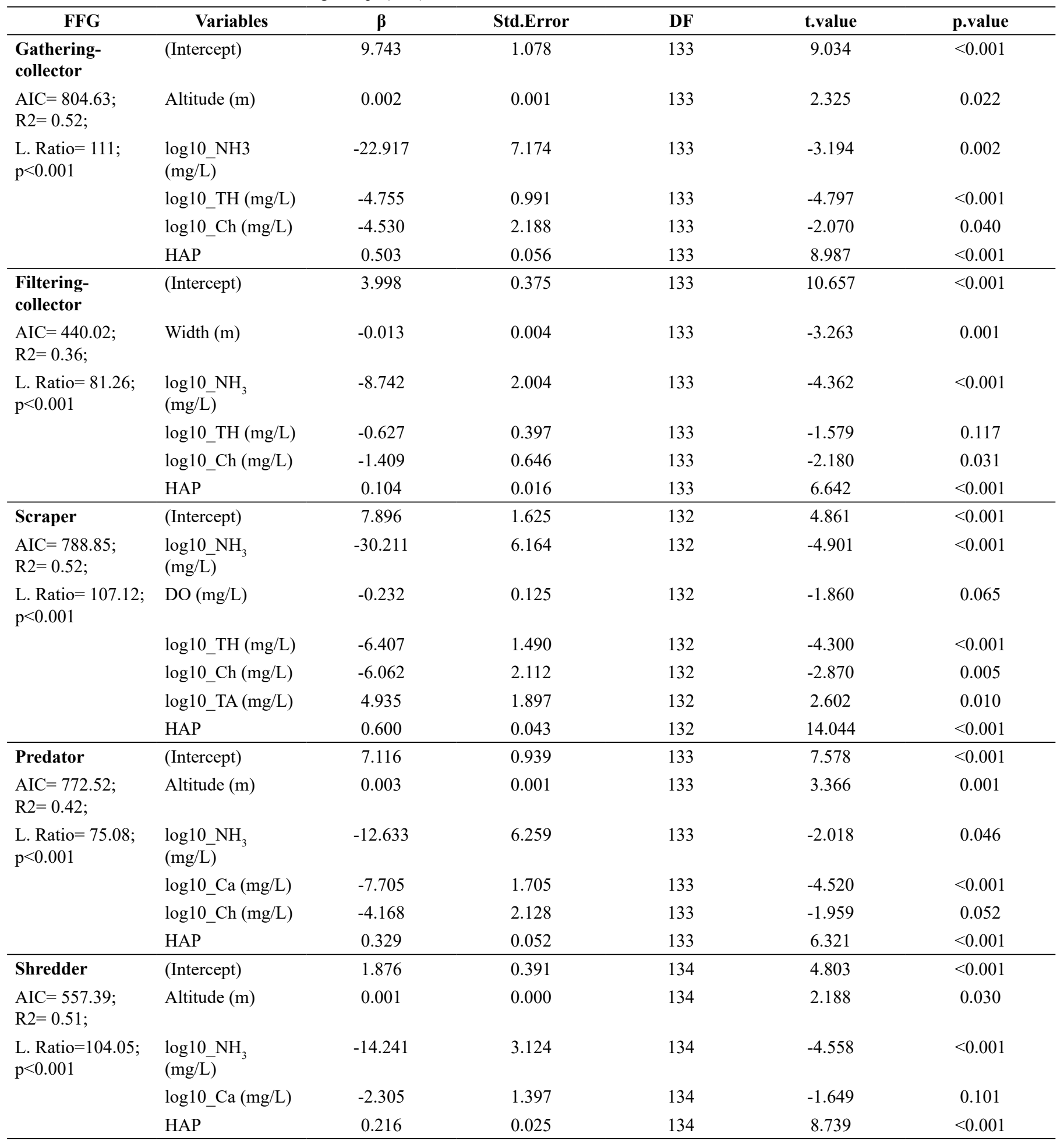

AIC- Akaike Information Criterion, $\mathrm{R}^{2}$ - Coefficient of Determination, L.Ratio- Likelihood Ratio, $\mathrm{p}$-value- $\mathrm{p}$-value after Likelihood Ratio Test, DF - Degrees of Freedom. Log10_NH - Ammonia; Log10_TH- Total Hardness, Log10_Ch- Chloride, HAP- Habitat Assessment Protocol, DO- Dissolved Oxygen, Log10_TATotal Alkalinity and Log10_Ca-Calcium. 


\section{Discussion}

Anthropogenic activities may impact stream ecosystems by causing habitat fragmentation, degradation, sedimentation, which consequently increase the abundance of tolerant species and a decrease of sensitive species (Mangadze et al. 2019). In our study, the abundance of gathering and filtering collectors and predators were higher at intermediate sites. In contrast, abundance and richness of scrapers and shredders were negatively correlated with the impairment gradient. Gathering collectors are often recognized as generalists and are considered dominant along the impairment gradient (Leslie \& Lamp 2017). They can also transform the decomposition of Fine Particulate Organic Matter (FPOM) and carbon availability within the sediment (Leslie \& Lamp 2017). In our study, filtering collectors were the most abundant FFG along the impairment gradient, due to large numbers of Simuliidae in urban areas. These organisms are reasonably resistant to disturbance (Feld et al. 2002). Furthermore, significant differences were found for scraper abundance between reference, intermediate, and impaired sites. According to Jun et al. (2011), scrapers are sensitive to impairment because they mainly consume attached algae that grow on the cobbles and pebbles of undisturbed streams. As for predators, we found lower mean abundance at impaired sites than the intermediate site. Predator abundance appears to be driven mainly by prey availability and have studies found an increased abundance in streams affected by human activities (RawerJost et al. 2000). As expected, the abundance of shredders was reduced along the stream impairment gradient because of reduced quantities of riparian vegetation. Similar results were found by Oliveira $\&$ Nessimian (2010) that reported lower relative participation of this FFG on impaired sites. Although shredder abundance was very low, we found significant differences between reference and impaired sites.

Richness numbers displayed the best response and highest sensitivity to detect impairment. Richness numbers of all FFG were significantly reduced along the impairment gradient stream. Richness can have an essential function in characterizing stream ecosystem condition (Kaboré et al. 2016, Couceiro et al. 2011, Drover et al. 2020).

Estimated marginal means based on regression analyses (mixed-effect models) showed that the altitude was a significant abiotic variable for all FFG abundance, except for the filtering collector. According to Jacobsen (2008), one possible explanation is that at higher altitudes, streams tend to have lower temperatures and higher slopes, contributing to higher concentrations of DO. Tomanova et al. (2007) showed that altitude combined with position along the longitudinal gradient is an important factor controlling the FFG assemblages of stream macroinvertebrates in neotropical streams. In this study, the richness of all FFGs was reduced along the impairment gradient. These reductions were correlated to the increase of $\mathrm{NH}_{3}$ for all FFG. According to Camargo (2019), physicochemical alterations, such as the increase of ammonia $\left(\mathrm{NH}_{3}\right)$, can be toxic to sensitive macroinvertebrate taxa. Also, it is well known that large-scale agriculture and urbanization may decrease water quality leading to alterations as the loss of riparian vegetation with a significant effect on the FFG structure and function (Gieswein et al. 2019). Streams in this region are subject to different pressures, including intensive urbanization and untreated sewage discharges. Most sites suffered the influence of multiple chemical and physical anthropogenic stressors. Agriculture and urban land-use practices reduce water quality due to inputs of fine sediments, nutrients, and pesticides. Alterations to the river channel's physical structure may cause a loss in riparian vegetation, which would be expected to produce a significant effect on FFG structure (Fu et al. 2016).
FFG ratios showed a variable response along the impairment gradient. The Autotrophic/Heterotrophic index (A/H) serves as a surrogate of Production/Respiration $(\mathrm{P} / \mathrm{R})$, which was significantly different along the impairment gradient. $\mathrm{P} / \mathrm{R}$ has been used as the relative importance of energy fixed by primary producers (Vannote et al. 1980), i.e., $\mathrm{P} / \mathrm{R}$ ratios among ecosystems are proxies of allochthonous ratio/autochthonous organic matter. According to this criterium, even though reference sites had higher estimated marginal mean values, almost sites in our study were classified as heterotrophic, independent of their position along the impairment gradient. These results follow Cummins et al. (2005), who also found that all sampled sites on their study of the Atlantic Forest stream of Southern Brazil could be characterized as heterotrophic. Other tropical/subtropical streams in Kenya also classified close-canopy streams as heterotrophic (Masese et al. 2014). According to the Coarse Particulate Organic Matter/Fine Particulate Organic Matter index (CPOM/FPOM), a shallow shredder interaction with riparian vegetation was found in impaired sites. According to Cummins et al. (1989), this decline is most probably related to the removal of riparian vegetation from agricultural and urban areas. We also found a TFPOM/BFPOM index unresponsive to the impairment gradient, which agrees with Couceiro et al. (2011). Moreover, the Habitat Stability index (HSI) indicated stable substrates that were more abundant in intermediate sites. One explanation for these results would be the intermediate disturbance hypothesis (Ward \& Stanford 1983, Ward et al. 1999). Intermediate sites were submitted to constant sewage discharges. It seems to generate moderate mortality in the species not in such numbers that a recovery is impossible, but at the same time, sufficient to limit the growth of competitive species. For the Predator index, it was observed a low top-down control in reference and intermediate sites. Almost all FFG ratios showed significant differences along the impairment gradient. This observation does not agree with Kaboré et al. (2016), which found inconsistent results in different land use in West Africa.

FFG ratios as a surrogate of the ecosystem attributes may reduce the time and costs of the evaluation being fast, cheaper, and an integrated tool based on morphological and behavioral mechanisms of food acquisition. Moreover, this study evaluated marginal mean estimates for FFG ratio, abundance, and mostly for richness, as a useful tool to assess the ecological conditions of Atlantic Forest streams. Despite the almost FFG ratio being able to discriminate along the impairment gradient, further studies would be necessary to calibrate the method specifically for the Atlantic Forest region.

\section{Supplementary Material}

The following online material is available for this article: Appendix 1 - Summary of the abiotic variables (mean value \pm standard error) investigated along the impairment gradient. Appendix 2 - Functional Feeding Groups (FFG) for Atlantic Forest taxa.

\section{Acknowledgments}

The work by supported by Conselho Nacional de Desenvolvimento Científico e Tecnológico (CNPQ/PROEP 400107/2011-2). Doctoral scholarship (FIOCRUZ-PPGBS). We are grateful to technical Valdinei Valin for in carrying out physicochemical analysis. 


\section{Author Contributions}

Priscilla da Silva Pereira: Substantial contribution in the concept and design of the study, contribution to data collection, contribution to data analysis and interpretation, contribution to manuscript preparation, contribution to critical revision, adding intellectual content.

Natália Freitas de Souza: Contribution to manuscript preparation and adding intellectual content.

Darcílio Fernandes Baptista: Contribution to manuscript preparation and to critical revision, adding intellectual content.

Marcelo Ribeiro-Alves: Substantial contribution to manuscript preparation and critical revision, adding intellectual content, contribution to data analysis and interpretation.

Helena Lúcia Carneiro Santos: Substantial contribution to manuscript preparation and critical revision, adding intellectual content

Daniel Forsin Buss: Contribution to manuscript preparation and to critical revision, adding intellectual content.

\section{Conflicts of interest}

The authors declare that there is no conflict of interest related to the publication of the data in this article.

\section{References}

ALLAN, J.D. \& CASTILHO, M.M. 2007. Stream ecology: structure and function of running waters. $2^{\text {nd }}$ edition, Springer, Dordrecht.

ALVARES, C.A., STAPE, J.L., SENTELHAS, P.C., GONÇALVES, J.L.M. \& SPAROVEK, G. 2013. Köppen's climate classification map for Brazil. Meteorol. Z. 22(6):711-728.

APHA, AWWA, WPCF. 2000. Standard methods for the examination of water and wastewater, 20th ed. American Public Health Association/American. Water Works Association/Water Environment Federation. Washington, DC.

BARBOUR, M.T., GERRITSEN, J., SNYDER, B.D. \& STRIBLING, J.B. 1999 Rapid Bioassessment Protocols for use in streams and wadeable rivers: Periphyton, Benthic Macroinvertebrates and Fish, 3rd ed. Washington: U.S. Environmental Protection Agency; Office of Water, EPA 841-B-99-002.

BAPTISTA, D.F., BUSS, D.F., DIAS, L.G., NESSIMIAN, J.L., Da SILVA, E.R., NETO, A.D.M. \& ANDRADE, L.R. 2006. Functional feeding groups of Brazilian Ephemeroptera nymphs: ultrastructure of mouthparts. Ann. Limnol-Int. J. Lim. 42(2):87-96.

BAPTISTA, D.F., BUSS, D.F., EGLER, M., GIOVANELLI, A., SILVEIRA, M.P. \& NESSIMIAN, J.L. 2007. A multimetric index based on benthic macroinvertebrates for evaluation of Atlantic streams at Rio de Janeiro State, Brazil. Hydrobiologia 575: 83-94.

BONADA, N., PRAT, N., RESH, V.H. \& STATZNER, B. 2006. Developments in aquatic insect biomonitoring: comparative analysis of recent approaches. Annu. Rev. Entomol. 51:495-523.

BRASIL. Ministério das Minas e Energia. Secretaria Geral., 1983. Projeto RADAMBRASIL: Folha SD. 23 Rio de Janeiro, Levantamento de Recursos Naturais, v. 29660 p.

BRASIL, L.S., JUEN, L., BATISTA, J.D., PAVAN, M.G. \& CABETTE, H.S.R. 2014. Longitudinal distribution of the functional feeding groups of aquatic insects in streams of the Brazilian Cerrado Savanna. Neotrop. Entomol. 43(5):421-428.

BUSS, D.F, CARLISLE, D.M., CHON, T.S, CULP, J., HARDING, J.S, KEIZER-VLEK, H.E \& HUGHES, R.M. 2015. Stream biomonitoring using macroinvertebrates around the globe: a comparison of large-scale programs. Environ. Monit. Assess. 187(1):4132.

CAMARGO, J.A. 2019. Positive responses of benthic macroinvertebrates to spatial and temporal reductions in water pollution downstream from a trout farm outlet. Knowl. Manag. Aquat. Ec. 420:16.
CENEVIVA-BASTOS, M., PRATES, D.B., de MEI ROMERO, R., BISPO, P.C. \& CASATTI, L. 2017. Trophic guilds of EPT (Ephemeroptera, Plecoptera, and Trichoptera) in three basins of the Brazilian Savanna. Limnologica. 63:11-17.

COUCEIRO, S.R.M., HAMADA, N., FORSBERG, B.R. \& PADOVESIFONSECA, C. 2011. Trophic structure of macroinvertebrates in Amazonian streams impacted by anthropogenic siltation. Austral Ecol. 36(6):628-637.

CUMMINS, K.W. 1973. Trophic relations of aquatic insects. Annu. Rev. Entomol. 18:183-206.

CUMMINS, K.W. 2018. Functional Analysis of Stream Macroinvertebrates. In Limnology. IntechOpen.

CUMMINS, K.W. \& KLUG, M.J. 1979. Feeding ecology of stream invertebrates. Annu. Rev. Ecol. S. 10:147-172.

CUMMINS, K.W., MERRITT, R.W. \& ANDRADE, P.C.N. 2005. The use of invertebrate functional groups to characterize ecosystem attributes in selected streams and rivers in south Brazil. Stud. Neotrop. Fauna E. 40(1):69-89.

CUMMINS, K.W., WILZBACH, M.A., GATES, D.M., PERRY, J.B., TALIAFERRO, W.B. 1989. Shredders and riparian vegetation. BioScience 39(1):24-30.

DEDIEU, N., RHONE, M., VIGOUROUX, R., \& CÉRÉGHINO, R. 2015. Assessing the impact of gold mining in headwater streams of Eastern Amazonia using Ephemeroptera assemblages and biological traits. Ecol. Indic. 52:332-340.

DROVER, D.R., SCHOENHOLTZ, S.H., SOUCEK, D.J. \& ZIPPER, C.E. 2020. Multiple stressors influence benthic macroinvertebrate communities in central Appalachian coalfield streams. Hydrobiologia 847(1): 191-205.

DURANCE, I. \& ORMEROD, S.J. 2007. Climate change effects on upland stream macroinvertebrates over a 25 -year period. Global Change Biol. 13(5): 942-957.

FELD, C.K., KIEL, E. \& LAUTENSCHLÄGER, M. 2002. The indication of morphological degradation of streams and rivers using Simuliidae. Limnologica 32(3):273-288.

FERNANDES, L.A.C. 2015. Relações comprimento massa seca para estimativa de biomassa de insetos aquáticos tropicais. Dissertação de mestrado, Escola Nacional de Saúde Pública Sergio Arouca. Rio de Janeiro.

FU, L., JIANG, Y., DING, J., LIU, Q., PENG, Q.Z. \& KANG, M.Y. 2016. Impacts of land use and environmental factors on macroinvertebrate functional feeding groups in the Dongjiang River basin, southeast China. J. Freshwater Ecol. 31(1):21-35.

FUGÈRE, V., JACOBSEN, D., FINESTONE, E.H. \& CHAPMAN, L.J. 2018. Ecosystem structure and function of afrotropical streams with contrasting land use. Freshw. Biol. 63(12):1498-1513.

GIESWEIN, A., HERING, D. \& LORENZ, A.W. 2019. Development and validation of a macroinvertebrate-based biomonitoring tool to assess fine sediment impact in small mountain streams. Sci. Total Environ. 652:1290-1301.

HAWKINS, C.P. \& SEDELL, J.R. 1981. Longitudinal and seasonal changes in functional organization of macroinvertebrate communities in four Oregon streams. Ecology 62(2):387-397.

HENRIQUES-OLIVEIRA, A.L. \& NESSIMIAN, J.L. 2010. Aquatic macroinvertebrate diversity and composition in streams along an altitudinal gradient in Southeastern Brazil. Biota Neotrop. 10:115-128.

JACOBSEN, D. 2008. Tropical high-altitude streams. In Tropical stream ecology Academic Press. Elsevier, London, p. 219-253.

JUN, Y.C., KIM, N.Y., KWON, S.J., HAN, S.C., HWANG, I.C., PARK, J.H., WON, D.H., BYUN, M.S., KONG, H.Y., LEE, J.E. \& HWANG, S.J. 2011 Effects of land use on benthic macroinvertebrate communities: comparison of two mountain streams in Korea. Ann. Limnol-Int. J. Lim. 47(1):S35-S49.

KABORÉ, I., MOOG, O., ALP, M., GUENDA, W., KOBLINGER, T., MANO, K., OUÉDA, A., OUÉDRAOGO, R., TRAUNER, D. \& MELCHER, A.H. 2016. Using macroinvertebrates for ecosystem health assessment in semiarid streams of Burkina Faso. Hydrobiologia 766:57-74.

LENTH, R.V. 2020. emmeans: Estimated Marginal Means, aka Least-Squares Means. R package version 1.4.7. URL https://CRAN.R-project.org/ package $=$ emmeans. 
LESLIE, A.W. \& LAMP, W.O. 2017. Taxonomic and functional group composition of macroinvertebrate assemblages in agricultural drainage ditches. Hydrobiologia 787: 99-110.

MACEDO, D.R., HUGHES, R.M., FERREIRA, W.R., FIRMIANO, K.R., SILVA, D.R.O, LIGEIRO, R. KAUFMANN, P.R. \& CALLISTO, M. 2016. Development of a benthic macroinvertebrate multimetric index (MMI) for Neotropical Savanna headwater streams. Ecol. Indic. 64:132-141.

MANGADZE, T., WASSERMAN, R.J., FRONEMAN, P.W. \& DALU, T. 2019. Macroinvertebrate functional feeding group alterations in response to habitat degradation of headwater Austral streams. Sci. Total Environ. 695:133910.

MASESE, F.O., KITAKA, N., KIPKEMBOI, J., GETTEL, G.M., IRVINE, K. \& McCLAIN, M.E. 2014. Macroinvertebrate functional feeding groups in Kenyan highland streams: evidence for a diverse shredder guild. Freshw. Sci. 33(2):435-450

MENDES, F., KIFFER, W.P. \& MORETTI, M.S. 2017. Structural and functional composition of invertebrate communities associated with leaf patches in forest streams: a comparison between mesohabitats and catchments. Hydrobiologia 800(1):115-127.

MERRITT, R.W. \& CUMMINS, K.W. 1996. An Introduction to the Aquatic Insects of North America. Third edition. Kendall-Hunt Publishing Company. Iowa, USA, p. 1-862.

MERRITT, R.W., CUMMINS, K.W., BERG, M.B., NOVAK, J.A., HIGGINS, M.J., WESSELL, K.J. \& LESSARD, J.L. 2002. Development and application of macroinvertebrate functional group approach in the bioassessment of remnant river oxbows in southwest Florida. J. N. Am. Benthol. Soc. 21:290-310.

MERRITT, R.W., HIGGINS, M.J., CUMMINS, K.W. \& VANDENEEDEN, B. 1999. The Kissimmee River-riparian marsh ecosystem, Florida: seasonal differences in invertebrate functional feeding group relationships. In: Batzer DP, Rader RB, Wissinger S, editors. Invertebrates in freshwater wetlands in North America: Ecology and management. John Wiley and Sons: New York, p. $55-79$.

MERRITT, R.W., WALLACE, J.R., HIGGINS, M.J., ALEXANDER, M.K., BERG, M.B., MORGAN, W.T., CUMMINS, K.W. \& VANDENEEDEN, B. 1996. Procedures for the functional analysis of invertebrate communities of the Kissimmee River-floodplain ecosystem. Fla. Scientist 59(4):216-274.

NESSIMIAN, J.L. 1997. Categorização funcional de macroinvertebrados de um brejo de dunas no Estado do Rio de Janeiro. Rev. Brasil. Biol. 57(1):135-145.

OLIVEIRA, R.B.S., MUGNAI, R., CASTRO, C.M., BAPTISTA, D.F. 2011. Determining subsampling effort for the development of a rapid bioassessment protocol using benthic macroinvertebrates in streams of Southeastern Brazil. Environ. Monit. Assess. 175:75-85.

OLIVEIRA, R.B.S., MUGNAI, R., PEREIRA, P.S., SOUZA, N.F. \& BAPTISTA, D.F. 2019. A predictive multimetric index based on macroinvetebrates for Atlantic Forest wadeable streams assessment. Biota Neotrop. 19(2):e20180541.
OLIVEIRA, A.L.H. \& NESSIMIAN, J.L. 2010. Spatial distribution and functional feeding groups of aquatic insect communities in Serra da Bocaina streams, southeastern Brazil. Acta Limnol. Bras. 22(4):424-441.

PINHEIRO, J., BATES, D., DEBROY, S. \& SARKAR, D. 2020. nlme: Linear and Nonlinear Mixed Effects Models. R package version 3.1-144, URL: https://CRAN.R -project.org/package=nlme.

RAWER-JOST, C., BÖHMER, J., BLANK, J. \& RAHMANN, H. 2000. Macroinvertebrate functional feeding group methods in ecological assessment. Hydrobiologia, 422:225-232.

R CORE TEAM, 2018. R: A language and environment for statistical computing. R Foundation for Statistical Computing, Vienna, Áustria. URL https://www.R-project.org/.

RIBEIRO, M.C., MARTENSEN, A.C., MEYZGER, J.P., TABARELLI, M., SCARANO, F. \& FORTIN, M.J. 2011. The Brazilian Atlantic Forest: a shrinking biodiversity hotspot. In Biodiversity hotspots pp. 405-434.

ROSENBERG, D.M. \& RESH, V.H. 1993. Freshwater Biomonitoring and Benthic Macroinvertebrates. Chapman and Hall, New York.

SOUZA, N.F.D., BAPTISTA, D.F. \& BUSS, D.F. 2019. Índice preditivo baseado em filtros ambientais para o biomonitoramento de rios em bacias sem áreas de referência no bioma Mata Atlântica, Brasil. Biota Neotrop. 19(1):e20180601.

TOMANOVA, S., GOITIA, E. \& HELESIC, J. 2006. Trophic levels and functional feeding groups of macroinvertebrates in neotropical streams. Hydrobiologia 556:251-264.

TOMANOVA, S., TEDESCO, P.A., CAMPERO, M., VAN DAMME, P.A., MOYA, N. \& OBERDORFF, T. 2007. Longitudinal and altitudinal changes of macroinvertebrate functional feeding groups in neotropical streams: a test of the River Continuum Concept. Fund. Appl. Limnol. 170:233-241.

VANNOTE, R.L., MINSHALL, G.W., CUMMINS, K.W., SEDELL, J.R. \& CUSHING, C.E. 1980. The river continuum concept. Can. J. Fish. Aquat. Sci. 37(1):130-137.

VELÁSQUEZ, S.M. \& MISERENDINO, M.L. 2003. Análisis de la materia orgánica alóctona y organización funcional de macroinvertebrados en relación con el tipo de hábitat en ríos de montaña de Patagonia. Ecol. Austral 13:67-82.

WARD, J.V. \& STANFORD, J.A. 1983. The intermediate disturbance hypothesis: an explanation for biotic diversity in lotic ecosystems. Pages 347-356 in T. D. Fontaine III and S. M. Bartell, editors. Dynamics of lotic ecosystems. Ann Arbor Science, Ann Arbor, Michigan, USA.

WARD, J.V., TOCKNER, K. \& SCHIEMER, F. 1999. Biodiversity of foodplain river ecosystems: ecotones and connectivity. Regul. Rivers: Res. Mgmt. 15:125-139.

Received: $14 / 04 / 2020$

Revised: 12/09/2020

Accepted: 14/09/2020

Published online: 16/09/2021 